\section{Abbreviated Lysosomes}

SIR,-The examples (Nature, 221, 129, 709; 1969) of subeditorial improvemonts are nice but timid and suggest only local tinkering. They impel me to try my hand at a more radical rewrite of the first sixteen lines of the paper by $D$. W. and M. S. Misch on the reversible activation of lysosomes by dimethyl sulphoxide (Nature, 221, 862; 1969).

\section{ORIGINAL}

WE have demonstrated that dimethyl sulphoxide (DMSO), used in concentrations which protect cells against damage caused by freezing and subsequent thawing, can increase the activity of rat liver lysosomes, in vitro, as measured by increased activity of acid phosphatase. The presence of DMSO in sufficient concentration apparently increases the permeability of rat liver lysosomes to the sodium-betaglycerophosphate used as substrate, thereby increasing the activity of the enzyme, which was originally masked or latent. Our previous experiments also indicated that DMSO, despite releasing some acid phosphatase from lysosomes in the conditions used, might not permanently alter the lysosomal membrane.

We have now shown that the effect of DMSO is reversible, at least in part, and does not permanently alter the lysosome.

\section{REWRITTEN VERSION}

OuR last paper showed that DMSO in sufficient concentration releases acid phosphatase from rat-liver lysosomes in vitro (apparently by making them more permeable to the sodium-beta-glycerophosphate used as substrate). We can now confirm that, as then suggested, this process is at least partly reversible.

Of course I know nothing about the subject matter and may have failed to see where legitimate misunderstandings were being fended off: Ihope the authors will bounce back. But I claim I deserve to get something out of a paper even when I know nothing of the field, and not to have to fight for it unnecessarily; which I take to be the nub of your editorial also (Nature, 221, 128; 1969).

$$
\text { Yours faithfully, }
$$

Peter Wexler

University of Essex,

Language Centre,

Wivenhoe Park, Colchester.

Essex.

SrR,-We "bounce back" to your attempt at rewriting the first lines of our paper, "Reversible Activation of Lysosomes by Dimethyl Sulphoxide" (Nature, 221, 862; 1969).

Your style reads much more easily than ours and we both prefer it in that regard. One problem, however, is the omission of such phrases as ". . . used in concentrations which protect cells against damage caused by freezing and subsequent thawing. ..." That description imparts a fair degree of information to those reading the report, regardless of their background.

It is just such relevance to which John Maddox refers (Nature, 221, 128; 1969). Since he also suggosts that Nature should retain the dual functions of a newsletter and a. journal for scholarly reports, we feel that your vorsion, although easier to read, is now too brief for a scientific report in Nature.

Yours truly, Donald W. Misch Margaret S. Misch

University of North Carolina,

Department of Zoology,

Chapel Hill,

North Carolina, USA.

\section{Indigence of Indian Science}

SIR,-I should like to comment on recent reviews of Indian science, the most notable of which is that byParthasarthi (Nature, 221, 909; 1969).

The universities have become the weakest links in Indian research, not because of a shortage of qualified personnel to supervise research, but because insufficient funds are available for even moderately sophisticated equipment. In addition, the CSIR and the Atomic Energy Authority establishments share not only the bulk of government research funds between them, but they also attract most of the qualified scientists (see Rahman et al., J. Ind. Sci. Res., October 1963). As a consequence, certain kinds of research that require sophisticated equipment that is available to undergraduate students in some countries cannot be carried out.

There is also a desperate shortage of library facilities. The proliferation of scientific literature, and at the same time an alarming shortage of foreign exchange in India, prevent even the big traditional universities and research institutions from having an up to date library. It is amazing that, working under such strained conditions, young Indian scientists are able to produce good work.

The cost structure of scientific research is also relevant in this context. A useful study by Hussain Zaheer et al. (Science Congress, 1963) showed that if the structure of research had not altered, by the early 1970 s about 70 per cent of the expenditure on laboratories would be taken up by salaries of scientific and administrative staff. This warning unfortunately escaped the notice of science administrators in India. The cost of books and equipment follows international price rates, while salaries follow the trend of a country's standard of living. Salaries in India are much lower than those in other countries, for example a senior scientist earns between $\$ 1,000$ and $\$ 2,000$, so the obvious policy for some time to come will be to invest much more on equipment, books and journals, and a scheme of optional use (through sharing) will have to be drawn up. Although India has started manufacturing scientific equipment, much greater efforts are needed.

The real imbalance in India is in terms of supply and production of scientists. The expected production of MSes by 1970 is about 8,500 $(1965: 6,571)$ and of BSes about 45,000 (1965: 35,046) a year. The country does not have adequate employment opportunity for such high qualified manpower, and at present about one-third of the output from science and engineering faculties faces unemployment. It is no wonder that the influx of Indian scientists into the United States and other countries cannot be avoided. For India, this is an unpalatable reality.

Scientific research cannot be treated in isolation from the social and political climate. Although Nehru was instrumental in drawing up a policy for science in 1958, much before many other advanced countries had an official science policy, unfortunately the society at large and the administrative community have always been sceptical of scientists and scientific research. Politicians question scientists, but do not know what to ask, and lack of communication between society and scientists has been disastrous for both-particularly in creating a milieu for applied research. The most important priority is therefore to create a scientific orientation in many more people, and only the future Indian political and social climate will dictate the future of science in post.Nehru India.

$$
\text { Yours faithfully, }
$$

Department of Mathematics,

$$
\text { A. Ghosal }
$$

Monash University,

Clayton, Australia. 